\title{
Artikel
}

\section{Duizelingwekkende en zorgwekkende ontwikkelingen in de rechtspositie van gedetineerden}

\author{
Prof.mr. S. (Sanne) Struijk*
}

\section{Inleiding}

Het gedetineerd zijn is als zodanig natuurlijk geen benijdenswaardige positie. Voor de mens is de individuele vrijheid immers nog altijd het hoogste goed. Maar het traditioneel humane karakter en de adequate materiële omstandigheden van de Nederlandse detentiesituatie maken over het algemeen dat het hier gedetineerd zijn in ieder geval nog te prefereren valt boven het gedetineerd zijn in de meeste andere landen. Toch staat juist dat humane, op het belang van de individuele gedetineerde gerichte karakter de laatste jaren stevig onder druk. In toenemende mate wordt in het penitentiair beleid niet alleen de doelmatigheid, maar ook de eigen verantwoordelijkheid van de gedetineerde vooropgesteld. Dit laatste geschiedt dan vanuit de neoliberale responsabiliseringsgedachte dat het gevangeniswezen zich nog slechts hoeft in te spannen om de gedetineerde zelf in staat te stellen zich op zijn terugkeer in de samenleving voor te bereiden, mits en zolang hij dat zelf tenminste wil, zich daarvoor inzet en daar ook zijn verantwoordelijkheid voor neemt. ${ }^{1}$ Een climax van die gedachte leek te zijn bereikt met de invoering in 2014 van het

Sanne Struijk is bijzonder hoogleraar penologie en penitentiair recht aan de Rijksuniversiteit Groningen en tevens universitair hoofddocent straf(proces)recht aan Erasmus School of Law.

1. Zie nader C. Kelk, 'Veranderende mensbeelden van gedetineerden. Een kort historisch overzicht', Justitiële Verkenningen 2015-5, p. 81-96 en F. de Jong, 'Responsabilisering in het Nederlandse straf-, sanctie- en detentierecht', Ars Aequi juli/augustus 2017, p. 640-652. beleidsprogramma 'Promoveren en degraderen in het gevangeniswezen'. ${ }^{2}$ Gebaseerd op het welhaast pedagogisch uitgangspunt dat goed gedrag dient te worden beloond en ongewenst gedrag dient te worden gecorrigeerd, krijgt die beloning sindsdien gestalte door een overeenkomstig handelende gedetineerde te plaatsen in het zogeheten plusprogramma en de tegenovergesteld handelende gedetineerde te plaatsen in het sobere basisprogramma.

Het onderliggend uitgangspunt heeft als zodanig brede steun gekregen, maar de opzet en uitvoering van het beleidsprogramma zijn van verschillende kanten geproblematiseerd en bekritiseerd. ${ }^{3}$ Niettemin gaan de ontwikkelingen in het penitentiaire veld in een sneltreinvaart verder. Het meest relevant in dit kader zijn de in 2018 door Minister voor Rechtsbescherming (minister Dekker) gepresenteerde visie op de tenuitvoerlegging van gevangenisstraffen, ${ }^{4}$ het begin 2019 van regeringswege ingediende wetsvoorstel Straffen en beschermen

2. Stcrt. 2014, 4617

3. Onder meer RSJ, Advies Wiiziging regeling SPOG in verband met promoveren en degraderen binnen het gevangeniswezen, Den Haag, 14 augustus 2013; M. Boone \& W. van Hattum, 'Promoveren en degraderen van gedetineerden. Het wetsvoorstel elektronische detentie en de dreigende afschaffing van de detentiefasering', NJB 2014-31, p. 2179-2184; E. van Ginneken, 'Zelfredzaamheid in detentie. Kritische kanttekeningen bij het systeem van promoveren en degraderen', Proces 2018 (97) 2, p. 113-129; T. de Groot \& P. Jacobs, 'Het systeem van promoveren en degraderen anno 2019: de rechtspraak van de beroepscommissie nader beschouwd', Sancties 2019/74, p. 333-344 en RSJ, Spanning in detentie, advies, Den Haag, 25 november 2019.

4. Visie Recht doen, kansen bieden; naar effectievere gevangenisstraffen (bijlage bij Kamerstukken // 2017/18, 29279, nr. 439). 
dat onlangs door de Eerste Kamer tot wet is verheven ${ }^{5}$ en de aanstaande wijziging van het promoveren-degraderen beleidsprogramma. ${ }^{6}$ Tel daarbij nog op de vele veranderingen ter zake van het forensische zorgstelsel, de implementatie van de Wet herziening tenuitvoerlegging strafrechtelijke beslissingen, ${ }^{7}$ de binnenkort in werking tredende Veegwet $^{8}$ en de tijdelijke coronamaatregelen en het is duidelijk dat het de meeste gedetineerden inmiddels zal duizelen. In deze bijdrage zal op enkele van de doorgevoerde en aangekondigde veranderingen worden ingegaan, waarbij zal worden betoogd dat zich al met al een forse achteruitgang van de rechtspositie van en rechtszekerheid voor gedetineerden voordoet.

\section{Veiligheid, vergelding en een nieuw stelsel van detentiefasering}

Voor wie nog de hoop had dat het resocialisatiestreven in het gevangeniswezen van overheidswege stevig werd uitgedragen, is met de kabinetsvisie 'Recht doen, kansen bieden' ruw wakker geschud. In deze visie worden uitdrukkelijk twee doelen van de gevangenisstraf vooropgesteld: veiligheid en vergelding. ${ }^{9}$ Het eerstgenoemd doel wordt hoofdzakelijk ingevuld als het verminderen van recidive; niet verwonderlijk gelet op de teneur van de afgelopen twee decennia van overheidsbeleid. Het tweede doel wordt ingevuld als de - kennelijk door de samenleving verlangde - vergelding van aangericht kwaad, ter genoegdoening voor het slachtoffer en de samenleving als geheel. Voor de Minister voor Rechtsbescherming is het voorts helder dat bij een afweging tussen de overkoepelende belangen van gedetineerden, slachtoffers en samenleving, de twee laatstgenoemde belangen voorop dienen te worden gesteld. ${ }^{10}$ De balans sloeg zijns inziens 'eerder te veel door naar de belangen van de gedetineerde', terwijl een straf 'echt een straf' moet zijn en ook zo moet worden ervaren. ${ }^{11}$ Nog afgezien van de vraag hoe dat laatste vanuit penologisch oogpunt moet worden bezien, ${ }^{12}$ lijkt deze insteek weinig

5. Kamerstukken I/ 2018/19, 35122, nrs. 1-3, respectievelijk de Wet straffen en beschermen, Stb. 2020, 224 (i.w.tr. naar verwachting op 1 mei 2021).

6. Bijlage 938174, p. 5, opgenomen bij Kamerstukken I 2019/20, 35122, nr. G.

7. Stb. 2017, 82 en Stb. 2019, 504, i.w.tr. op 1 januari 2020

8. Stb. 2019, 141, i.w.tr. naar verwachting op 1 januari 2021

9. Visie Recht doen, kansen bieden, a.w., p. 1-2.

10. Kamerstukken I/ 2018/19, 29279, 24587, nr. 532, p. 1 en Kamerstukken I 2019/20, 35122, nr. G.

11. Kamerstukken / 2019/20, 35122, nr. G, p. 2.

12. Onder meer in het licht van de bekende uitspraak van Alexander Paterson dat 'men are sent to prison as punishment, not for punishment.' Zie voor een mooie recente beschouwing over vergelding als penologisch doel voor vrijheidsbeneming P.H. van Kempen, ‘Rehabilitatie versus vergelding bij langdurig en levenslanggestraften - bevrijdende inzichten vanuit het EVRM?', in: J.P. Balkema e.a. (red.), Praktisch en veelzijdig, Deventer: Wolters Kluwer 2019, p. 169-182. bemoedigend voor de individuele gedetineerde die zijn ${ }^{13}$ detentieperiode zo positief en nuttig mogelijk tracht door te brengen. Toch wordt deze gedetineerde wel degelijk geholpen bij dat streven en worden hem kansen geboden op een succesvolle re-integratie in de samenleving. 'Straf is straf, maar de straf biedt ook kansen', zo luidt het adagium van de kabinetsvisie. Die kansen liggen in het beleid om reeds vanaf binnenkomst van de gedetineerde in de penitentiaire inrichting scherper te kijken naar en aan te sturen op diens hulpbehoefte ter zake van de gebieden werk en inkomen, identiteitsbewijs, zorg, schuldhulpverlening en onderdak. Hiertoe wordt ten aanzien van iedere binnenkomende gedetineerde een nieuwe zogeheten integrale intake gehouden, teneinde spoedig en met inbreng reeds van reclassering en gemeente een individueel detentie- en re-integratieplan (D\&R-plan) op te stellen. In de praktijk wordt hier veel van verwacht, temeer omdat de Wet straffen en beschermen (hierna: Wet senb) in een wettelijke grondslag voorziet voor niet alleen die integrale aanpak binnen de muren van de penitentiaire inrichting, maar ook voor de mogelijkheid tot uitwisseling van gegevens tussen DJI, 3 RO en gemeenten. ${ }^{14}$

Het privacy-aspect en eventuele uitvoeringsproblemen buiten beschouwing latend, kan deze ontwikkeling in het gemeenschappelijk belang zijn van zowel gedetineerden als samenleving. Een vroegtijdig samengesteld en breed gefundeerd trajectplan vergroot immers de kans op een succesvolle re-integratie en biedt bovendien enige houvast aan de gedetineerde gedurende het verloop van diens detentieperiode. ${ }^{15}$ Bovendien neemt de rechtszekerheid voor gedetineerden toe nu het D\&Rplan in de genoemde wet wordt overgeheveld van de Regeling SPOG naar (het nieuw in te voeren art. 18a van) de Penitentiaire beginselenwet $(\mathrm{Pbw})$. Het had echter aanbeveling verdiend om de beleidsmatige nadruk op de eigen verantwoordelijkheid van de gedetineerde voor het welslagen van diens re-integratie wettelijk te duiden door een nieuwe formulering dat het plan 'in overleg met de gedetineerde' wordt vastgesteld en aangepast, in plaats van de huidige open formulering dat dit 'zo veel mogelijk in overleg met de gedetineerde' geschiedt.

Die eigen verantwoordelijkheid van gedetineerden wordt nog steviger dan voorheen aangezet in zowel de kabinetsvisie als de Wet senb. Dit geschiedt door een versterking (sic!) van de overkoepelende 'persoonsgerichte aanpak', in die zin dat het gedrag van de gedeti-

13. Hieronder worden in deze bijdrage telkens ook alle niet-mannelijke gedetineerden verstaan.

14. Art. 18a jo. 18b Pbw nieuw. Zie tevens het bestuurlijk akkoord van DJI, Ministerie van Justitie en Veiligheid, VNG en reclassering, Kansen bieden voor re-integratie, d.d. 1 juli 2019 met bijbehorende Handreiking d.d. 19 december 2019

15. lets waar drie decennia geleden al voor werd gepleit: J.J.J. Tulkens, 'Vanuit het oogpunt van de gevangene', in: Sanctietoepassing: een nieuwe ordening, Gouda Quint 1991, p. 81-100 en C. Kelk, 'Het grote belang van een goed gestructureerde en rijke detentiefasering', Sancties $1993 / 2$, p. 69-81 
neerde zwaarder wordt meegewogen voor diens detentieverloop. Bleef (de beoordeling van) het individuele gedrag en de getoonde verantwoordelijkheid en inzet voor re-integratie tot nu toe beperkt tot het intramurale onderscheid tussen plaatsing in het basis- of in het plusprogramma - gefundeerd door de in artikel 2 lid 2 eerste volzin $\mathrm{Pbw}$ opgenomen zinsnede 'afhankelijk van het gedrag van de betrokkene ${ }^{16}$ - in de nieuwste wets- en beleidsontwikkelingen wordt dit uitgebreid tot de extramurale fases van verlof, penitentiair programma en voorwaardelijke invrijheidstelling (hierna: v.i.). Hieronder worden op hoofdlijnen de wijzigingen voor elk van deze drie fases belicht.

\section{Verlofstelsel op de schop}

In de kabinetsvisie staat genoemd dat 'het verlofstelsel er anders uit komt te zien'. In minder bedekte termen kan worden gesteld dat dit stelsel geheel op de schop gaat. Als uitvloeisel van de Wet senb worden de thans vrijwel automatisch toegekende verlofvormen van het algemene verlof en het regimesgebonden verlof in de (Z)BBI vervangen door het zogeheten re-integratieverlof. Niet te verwarren met het gelijknamig re-integratieverlof van levenslanggestraften, ${ }^{17}$ behelst dit een nieuw verlofsysteem waarbij per gedetineerde een individuele beslissing wordt genomen over het type verlof waarvoor hij in aanmerking komt - kortdurend re-integratieverlof, langdurend re-integratieverlof, of re-integratieverlof voor extramurale arbeid in een beperkt beveiligde afdeling - en of en met welke frequentie hem die mogelijkheid in concreto ook wordt verleend. De grondslag voor die beslissing is meervoudig. In de eerste plaats - het zal niet geheel uit de lucht komen vallen - betreft dat het individuele gedrag van de gedetineerde. Wettelijk wordt dat verankerd in de - in het nieuwe artikel 18a lid 2 onder c Pbw opgenomen - bepaling dat het D\&R-plan in ieder geval omvat 'het verlof waarvoor de gedetineerde bij goed gedrag in aanmerking komt.' Ook in de bijbehorende regelgeving zal een en ander moeten worden doorgevoerd, meer concreet in de Regeling Tijdelijk verlaten van de inrichting (RTVI). Die wijzigingen zijn momenteel nog in ontwikkeling. In deze bijdrage kan en zal daarom enkel worden uitgegaan van een conceptversie. Volgens deze versie wordt onder goed gedrag verstaan 'de mate waarin en de wijze waarop de gedetineerde door zijn gedrag gedurende de gehele detentie heeft doen blijken van een bijzondere geschiktheid tot terugkeer in de samenleving' (art. 15 lid 2 onder a RTVI concept). De soortgelijke omschrijving van 'goed gedrag' in artikel 1 onder $\mathrm{v}$ Pbw wordt zodoende uitgebreid van het niveau van interne vrijheden naar tevens het niveau van externe vrijheden.

16. Ingevoegd met de Instellingswet Raad voor strafrechtstoepassing en jeugdbescherming 2015, Stb. 2015, 140 (i.w.tr. op 1 juli 2015, Stb. 2015, 166).

17. Art. 20d Regeling tijdelijk verlaten van de inrichting (Stcrt. 2017, 48627, i.w.tr. op 1 september 2017).
Aan dat individuele gedrag zit voorts de wijziging gekoppeld dat verlof slechts wordt verleend als het een concreet, persoonsgericht, in het D\&R-plan opgenomen re-integratiedoel dient (art. 18a lid 2 onder b Pbw nieuw jo. art. 15 lid 1 RTVI concept). De nadere invulling van een dergelijk doel zal zich moeten uitwijzen, maar voor zover het ziet op het buiten de muren van de penitentiaire inrichting om kunnen regelen van praktische, voor de re-integratie noodzakelijke zaken is deze wijziging als zodanig onnodig, angezien de huidige verlofregeling daar reeds in voorziet (art. 31 RTVI). En voor zover het benodigd re-integratiedoel al te zeer en al te functioneel zal worden ingevuld langs de lijn van 'goed gedrag wordt beloond, slecht gedrag bestraft', ${ }^{18}$ is deze wijziging zelfs problematisch, vooral waar het een bezoek aan het sociale netwerk - gezin, familie, pleegouders etc. - betreft. Dat zou in mijn optiek geen onderdeel moeten uitmaken van het bestraffingsarsenaal voor 'slecht gedrag'. Het door het kabinet gevoelde bezwaar van een te vrijblijvend verlofstelsel ${ }^{19}$ weegt immers niet op voorhand zwaarder dan het belang van een zo stabiel en stevig mogelijk sociaal netwerk van de gedetineerde, om hem bij diens invrijheidstelling zo zacht mogelijk in de vrije samenleving te laten 'landen'. ${ }^{20}$

In het nieuwe verlofstelsel wordt als gezegd bij de individueel te nemen beslissing over verlof niet enkel het gedrag van de gedetineerde en diens inspanningen voor een succesvolle re-integratie meegewogen. De tweede beoordelingsfactor in dezen betreft de slachtofferbelangen en ook dat is niet nieuw. De slachtofferbelangen kunnen bijvoorbeeld reeds worden behartigd door het verbinden van een contact- of locatieverbod als bijzondere voorwaarde aan het verlof (art. 26 lid $3 \mathrm{Pbw}$ jo. art. 5 lid 2 RTVI), al dan niet gefundeerd op een risicoanalyse in het kader van een OM-executieadvies ex art. 6:1:10 Sv jo. art. 7 lid 2 Penitentiaire maatregel $(\mathrm{Pm})$ (voorheen de door het $\mathrm{OM}$ geplaatste executieindicator ex art. 1 onder $\mathrm{c} \mathrm{Pm}$ oud). ${ }^{21}$ In de parlementaire behandeling van het wetsvoorstel SenB is het belang om langs deze weg (versterkt) tegemoet te komen aan de beschermingsbehoefte van slachtoffers, van meet af aan benadrukt. Het gaat daarbij volgens de minister niet enkel om de (fysieke) veiligheid van slachtoffers, maar

18. Waarvan de kabinetsvisie sterk doet getuigen, zie onder meer Visie Recht doen, kansen bieden, a.w., p. 3.

19. Hetgeen in de kabinetsvisie overigens niet nader wordt verantwoord dan met verwijzing naar een onderzoek uit 2006: P.Ph. Nelissen e.a., Het tijdelijk verlaten van de inrichting. Een onderzoek naar besluitvorming bij het algemeen en regimesgebonden verlof voor gedetineerden, WODC 2006, als bijlage 10955 bij Kamerstukken /I 2006/07, 24587, nr. 209.

20. Dit belang wordt onder meer door het EHRM onderkend. Zie nader S. Meijer \& E.F.J.C. van Ginneken, 'Visie op resocialisatie?', Strafblad 2018/44, p. 35-41.

21. Ook buiten de verlofregeling om, zijn er reeds vele juridische mogelijkheden om verdachten en veroordeelden te binden aan contact- en locatieverboden teneinde slachtoffers en nabestaanden te beschermen. Zie voor een evaluatieonderzoek ter zake T.F.C. Fischer, I.W.M. Cleven \& S. Struijk, Handhaving en veiligheid bij strafrechtelijke contact-, locatie- en gebiedsverboden ter bescherming van slachtoffers, WODC projectnummer 2710, Erasmus Universiteit Rotterdam 2019. 
ook om veiligheidsgevoelens, bijvoorbeeld het belang van slachtoffers om niet onnodig met de verdachte te worden geconfronteerd. ${ }^{22}$ Naast de continuering en versteviging van de bestaande beschermingsbehoefte wordt in het nieuwe verlofstelsel wel degelijk een andere loot aan de stam van slachtofferbelangen toegevoegd. Onder deze belangen wordt namelijk mede verstaan de door de gedetineerde geleverde inspanningen om de door het strafbare feit veroorzaakte schade te vergoeden. ${ }^{23}$ Deze voor de tenuitvoerlegging atypische, want op het verleden gerichte beoordelingsfactor ter genoegdoening voor het slachtoffer, heb ik elders reeds bekritiseerd omdat financieel onvermogen van een gedetineerde niet in de weg mag komen te staan aan doorfasering. ${ }^{24}$ Ook indien het louter een symbolische functie heeft, waar de memorie van toelichting blijk van geeft ${ }^{25}$ - een als zodanig realistische blik, aangezien veel gedetineerden schulden hebben en ze bovendien tijdens hun detentieperiode geringe inkomsten kunnen verkrijgen via de penitentiaire arbeid - bestaat er mijns inziens geen grond om dergelijke financiële inspanningen als beoordelingsfactor voor verlofverlening aan te leggen.

De derde en laatste beoordelingsfactor is evenmin nieuw en betreft een inschatting van de mogelijkheid tot beperking en beheersing van de eventuele risico's bij verlof (inhoudende het risico op recidive en het risico voor slachtoffers of nabestaanden). ${ }^{26}$ Dit is staande praktijk, waarbij uitgevoerde risicoanalyses er zelfs toe kunnen leiden dat het verlof wordt geweigerd (art. 4 RTVI). In zoverre zou het een goede zaak zijn als het recent ontwikkeld en thans in de pilotfase verkerend instrument van de 'risicoscreener'27 een kwaliteitsimpuls zou geven aan de beoordeling van de risico's. Dat kan immers de mede daarop gebaseerde besluitvorming over de verlening van vrijheden ten goede komen en bovendien meer gewicht geven aan de vaststelling van het D\&R-plan van de gedetineerde.

Al met al zijn het dus niet zozeer de drie aspecten (kort gezegd, individueel gedrag van de gedetineerde, slachtofferbehoeften en risicobeperking) zelf die nieuw zijn of doen verbazen. Voor de twee laatstgenoemde aspecten bestaat zelfs sinds 1 juli 2015 de fundamentele grondslag van de in artikel 2 lid $2 \mathrm{Pbw}$ opgenomen tweede volzin dat bij het verlenen van vrijheden aan gedetineerden rekening wordt gehouden met de veiligheid van de samenleving en de belangen van slachtoffers en nabe-

22. Kamerstukken I 2019/20, 35122, nr. E, p. 4. Hoe dit aspect in de praktijk dient te worden beoordeeld, wordt niet geconcretiseerd, anders dan de enigszins geruststellende opmerking dat enkel 'een gevoel van onbegrip of onbehagen bij het slachtoffer' daarvoor onvoldoende is.

23. Kamerstukken // 2018/19, 35122, nr. 3, p. 11, alsook art. 15 lid 2 onder c RTVI concept.

24. S. Struijk, 'Wetsvoorstel Straffen en beschermen: wordt het kind met het badwater weggegooid?', Sancties 2020/13, p. 56-65, p. 62.

25. Kamerstukken // 2018/19, 35122, nr. 3, p. 11.

26. Art. 15 lid 2 onder b en c, RTVI concept.

27. Bijlage 938174, p. 5, opgenomen bij Kamerstukken I 2019/20, 35122, nr. G. staanden. ${ }^{28}$ Het feit dat deze als beperkingsgronden aan het resocialisatiebeginsel zijn gesteld, is in de literatuur op kritiek gestuit. Toch wordt er nu dus een nieuw verlofsysteem opgetuigd waarbij de genoemde aspecten een zwaardere status verkrijgen, door onmiskenbaar de basis te gaan vormen voor individuele besluitvorming over het verlenen van verlof. De vrijblijvendheid bij gedetineerden, zo deze al aanwezig is, wordt zodoende vervangen door onzekerheid. Waar men immers het eigen gedrag gedurende de detentie nog deels in de hand heeft - uiteraard tot op zekere hoogte, want het onvermogen tot zelfredzaamheid en zelfreflectie bij een groot deel van de huidige gedetineerdenpopulatie wordt inmiddels breed onderkend - geldt dat niet voor de andere twee externe beoordelingsaspecten.

Die onzekerheid over of verlof wordt verleend en vervolgens hoe die beslissing dan concreet wordt gestaafd, gaat er beslist toe leiden dat een groter appel op de beklag- en beroepsrechtspraak wordt gedaan. Dit, terwijl de beklagcommissies en beroepscommissie thans al onder druk staan, zo blijkt mede uit recent onderzoek van de RSJ. ${ }^{29}$ Dit heeft volgens de RSJ een meervoudige oorzaak, van onder meer het al jarenlang gestaag toenemend aantal klachten en de bijgevolg toegenomen moeite voor beklagcommissies en beroepscommissie om aan de (streef)termijn van afdoening te voldoen, alsook een 'verharding van de verhoudingen binnen detentie' als gevolg waarvan er een 'vicieuze cirkel lijkt te bestaan tussen de werkdruk van het personeel en de grote hoeveelheid klachten'. Het personeel zou namelijk minder tijd hebben voor bemiddeling en voor (de relatie met) de gedetineerde zelf, waardoor vervolgens voor de gedetineerde de weg van beklag en beroep resteert. Voor de bemiddeling komt er met de inwerkingtreding van de zogeheten Veegwet ${ }^{30}$ een steviger wettelijke basis middels het nieuw ingevoegd hoofdstuk XA van de Pbw. Volgens het daarin opgenomen centrale artikel 59a lid 1 Pbw heeft de gedetineerde het recht zich, mondeling of schriftelijk, tot de commissie van toezicht te wenden met het verzoek te bemiddelen ter zake van een grief omtrent de wijze waarop de directeur, een ambtenaar of een medewerker zich in een bepaalde aangelegenheid jegens hem heeft gedragen of een bij of krachtens deze wet gestelde zorgplicht heeft betracht. Voor de bemiddeling en de gewenste uitkomst van een 'voor beide partijen aanvaardbare oplossing' geldt op grond van lid 2 een streeftermijn voor de commissie van toezicht - concreet de maandcommissaris of een ander commissielid - van vier weken. Dit brengt dus een nieuwe werklast mee voor de commissies van toezicht, ${ }^{31}$ die

28. Instellingswet Raad voor strafrechtstoepassing en jeugdbescherming 2015, Stb. 2015, 140 en 166.

29. Zoals recent nog gesignaleerd in het RSJ-advies Spanning in detentie, a.w.

30. Stb. 2019, 141, i.w.tr. naar verwachting op 1 januari 2021

31. Ook de gedetineerde is overigens aan voorschriften gebonden indien hij gebruik wenst te maken van bemiddeling (daartoe bestaat gelukkig voor hem geen plicht teneinde (tevens) beklag in te kunnen stellen). Zie daarover nader P.C. Vegter, 'Veegt de Veegwet schoon?', Sancties 2020/14, p. 66-76 
voorts om praktische redenen nog extra zal toenemen door de wettelijke bepaling dat een commissielid niet deelneemt aan de behandeling van het klaagschrift, 'indien hij heeft bemiddeld ter zake van de beslissing waarop het klaagschrift betrekking heeft of daarmee op enige andere wijze bemoeienis heeft gehad' (art. 62 lid 1 tweede volzin Pbw nieuw). Hoe zuiver die bepaling ook is vanuit rechtspositioneel oogpunt, voor met name de kleinere commissies van toezicht wordt dit een fors logistiek probleem bij de samenstelling van de meervoudige beklagcommissie. Om de bemiddeling werkelijk te verstevigen met hopelijk bijgevolg een positief effect op zowel de penitentiaire verhoudingen als de doorloopsnelheden van de beklag- en beroepsrechtspaak, is het zeer aan te bevelen dat de overheid hier rekenschap van geeft door onder meer te investeren in de capaciteit van deze rechtspraak.

Die aanbeveling geldt temeer nu het nieuwe verlofstelsel er als gezegd toe kan leiden dat de zelfredzaamheid van de gedetineerden zich (vooral) ook toont in het vaker indienen van beklag. Zeker nu het verlofstelsel op nog een ander, hier nog niet genoemd punt wordt gewijzigd. Uitgaande van de eerdergenoemde, in de kabinetsvisie stevig aangezette vergeldingsgedachte, komt de gedetineerde voortaan pas op een later moment gedurende zijn detentie in aanmerking voor verlof. In geval van een gevangenisstraf tot en met zes jaar komt een gedetineerde bijvoorbeeld op zijn vroegst in aanmerking voor langdurend re-integratieverlof indien ten minste de helft van de gevangenisstraf is ondergaan, met inachtneming bovendien van een feitelijke detentieduur van ten minste vier maanden en een strafrestant van maximaal twaalf maanden tot aan het moment van (voorwaardelijke) invrijheidstelling (art. 20 lid 3 RTVI concept). ${ }^{32}$ Voor zover het gaat om verlofbeslissingen verleend door de directeur van de penitentiaire inrichting namens de Minister voor Rechtsbescherming - te weten het kortdurend en het langdurend re-integratieverlof ingeval van een gevangenisstraf tot maximaal twee jaar en een gevangenisstraf langer dan twee jaar indien het eerste re-integratieverlof zonder incidenten is verlopen ${ }^{33}-$ betekent dit naar verwachting een toename van het aantal door de commissie van toezicht af te handelen klachten, omdat nu eenmaal ook het belang van verlof voor gedetineerden toeneemt.

32. In geval van een gevangenisstraf langer dan zes jaar wordt op grond van art. 20 lid 4 RTVI concept het aantal maanden dat een gedetineerde op zijn vroegst in aanmerking komt voor langdurend re-integratieverlof voorafgaande aan het moment waarop de (voorwaardelijke) invrijheidstelling kan aanvangen, berekend volgens een formule, gerelateerd aan de detentieduur, te weten: twaalf maanden + (anderhalve maand $x$ het aantal volle jaren boven zes jaar gevangenisstraf).

33. Zie art. 2 lid 2 RTVI concept jo. art. 18 lid 2 RTVI concept. In alle overige verlofgevallen beslist de senior selectiefunctionaris namens de Minister voor Rechtsbescherming, alsook te allen tijde over re-integratieverlof voor extramurale arbeid (art. 20a RTVI concept). Het valt te verwachten dat de gedetineerde op grond van een nog te wijzigen art. $17 \mathrm{Pbw}$ het recht heeft tegen deze beslissing een met redenen omkleed bezwaarschrift in te dienen.
Door deze aanscherping van de verloftermijnen komt het verlof, als al verleend, dicht tegen de andere twee extramurale fases aan te liggen: het penitentiair programma en de v.i.

\section{Ontkoppeling penitentiair programma en v.i.}

Nog meer dan de verlofmogelijkheden, genereert de deelname aan een penitentiair programma voor gedetineerden de belangrijke mogelijkheid te gewennen aan en op goede wijze terug te keren in de vrije samenleving. Onder de huidige wet- en regelgeving kan de duur van een dergelijk ministerieel erkend extramuraal programma van minimaal 26 uur per week aan activiteiten ten hoogste gelijk zijn aan een zesde deel van de aan de gedetineerde opgelegde vrijheidsstraf, direct voorafgaand aan de datum van invrijheidstelling (art. 4 Pbw jo. art. 3-10 Pm). Die opgelegde straf dient ten minste zes maanden te zijn en het strafrestant bij aanvang van de deelname aan het penitentiair programma dient ten minste vier weken en ten hoogste een jaar te bedragen. Kort samengevat duurt het penitentiair programma thans dus, afhankelijk van de opgelegde vrijheidsstraf, tussen vier weken en een jaar. De erop volgende invrijheidstelling van de gedetineerde hoeft niet onvoorwaardelijk te zijn, maar kan ook langs de v.i.-modaliteit geschieden. In dat geval worden aan het penitentiair programma verbonden voorwaarden (art. $9 \mathrm{Pm}$ ) en toezicht (art. 7a Pm) omgezet in aan de v.i. verbonden voorwaarden en toezicht (art. 6:2:11 Sv). Over deze 'stapeling' van penitentiair programma en v.i. bestaat in de praktijk al langer onvrede, deels omdat de voornoemde omzetting niet altijd op een logische, effectieve wijze blijkt te geschieden en deels omdat het als problematisch wordt ervaren dat een veroordeelde na herroeping van zijn v.i. binnen de wettelijke kaders toch mogelijkerwijs weer in aanmerking kan komen voor doorfasering naar een penitentiair programma. ${ }^{34}$ Vanuit het oogpunt van doelmatigheid en de door het kabinet aan de gevangenisstraf gestelde doelen van veiligheid en vergelding, wordt met de Wet senb integraal een einde gemaakt aan de stapeling van penitentiair programma en v.i. Uitgaande van de wettelijke regeling dat v.i. louter bij een vrijheidsstraf van meer dan een jaar wordt verleend - over de terminologie 'wordt verleend' later meer geschiedt dit vrij eenvoudig door de nieuwe wettelijke bepaling dat een gedetineerde nog slechts in de gelegenheid kan worden gesteld tot deelname aan een penitentiair programma indien hij 'een of meer onvoorwaardelijke vrijheidsstraffen ondergaat waarvan de duur onderscheidenlijk de gezamenlijke duur ten minste zes maanden en ten hoogste een jaar bedraagt' (art. 4 lid 2 Pbw nieuw).

34. Zie uitvoerig J. uit Beijerse e.a., De praktijk van de voorwaardelijke invrijheidstelling in relatie tot speciale preventie en re-integratie, Den Haag: Boom juridisch 2018. 
Bij vrijheidsstraffen van meer dan een jaar, oftewel de v.i.-waardige straffen, staat in de toekomst dus geen penitentiair programma meer open. Voor gedetineerden met een v.i.-waardige straf rest voorafgaand aan v.i.-verlening dan enkel het nieuwe, aangescherpte verlofstelsel. Nog los van de onzekerheid of verlof wordt verleend, waardoor in theorie de situatie kan bestaan dat een gedetineerde met v.i. gaat zonder eerst uitvoerig op verlof te zijn geweest, ${ }^{35}$ valt het nog te bezien of de aansluiting tussen de v.i.-periode en het mogelijk daaraan voorafgaand langdurig re-integratieverlof in de praktijk beter zal verlopen dan thans het geval is bij de overgang van penitentiair programma naar v.i. Dit geldt met name voor het type re-integratieverlof voor extramurale arbeid in een beperkt beveiligde afdeling. Het zou een goede zaak zijn als er voor die aansluiting reeds aandacht bestaat in het kader van de vijf pilots die momenteel worden uitgevoerd ter voorbereiding op de regionaal aan te wijzen beperkt beveiligde afdelingen. ${ }^{36}$ Overigens is thans de gedachte dat het re-integratieverlof voor extramurale arbeid zal zijn uitgesloten, zodra een gedetineerde deelneemt aan een penitentiair programma (art. 20b lid 3 eerste volzin RTVI concept), en andersom dat een gedetineerde die in een beperkt beveiligde afdeling is geplaatst niet in aanmerking zal komen voor deelname aan een penitentiair programma (art. 6 lid 1 onder $\mathrm{d}$ Pm concept, blijkens het concept Uitvoeringsbesluit Wet straffen en beschermen). Kennelijk wordt dit type verlof en deelname aan een penitentiair programma op voorhand aan elkaar gelijkgesteld, terwijl de daadwerkelijke inhoud en uitvoering ervan dat nog zal moeten doen uitwijzen en de gelijkstelling en onderlinge uitsluiting bovendien een forse verschraling van de detentiefasering zou inhouden voor deze groep gedetineerden. ${ }^{37}$ Van belang in dit verband is voorts dat de gedetineerde hier geen eigen keuze in lijkt te gaan hebben. In het geval hij in aanmerking komt voor zowel het re-integratieverlof voor extramurale arbeid als een penitentiair programma, is het volgens art. 20b lid 3 tweede volzin RTVI concept de senior selectiefunctionaris die (namens de Minister voor Rechtsbescherming) bepaalt welke modaliteit het wordt. Al met al verdient dit nadere overweging.

35. Met betrekking tot het gehele spectrum van gewenst gedrag, verlofverlening en v.i.-verlening wordt in de nadere memorie van antwoord bij het wetsvoorstel Senb nuancerend opgemerkt dat er 'ook met gedetineerden die niet het gewenste gedrag laten zien, wordt gewerkt aan een veilige terugkeer, door re-integratieactiviteiten in detentie' en het intramurale re-integratiecentrum. (Kamerstukken / 2019/20, 35122, nr. E, p. 5). Dat is natuurlijk een goede zaak, maar dat betreft reeds staand beleid en het had mijns inziens dus de voorkeur verdiend om dit te verstevigen, in plaats van het verlofstelsel fors aan te scherpen. Reintegreren is immers bij uitstek toch een proces dat in de vrije samenleving moet geschieden, op liefst graduele wijze.

36. Kamerstukken / 2019/20, 35122, nr. G, p. 7. Overplaatsing naar een dergelijke beperkt beveiligde afdeling kan overigens enkel bij gedetineerden aan wie dat type re-integratieverlof voor extramurale arbeid is verleend door, als gezegd, de senior selectiefunctionaris. Dat kan op zijn vroegst op een zesde deel van de straf voorafgaand aan de fictieve v.i.datum, met een maximum van twaalf maanden. Voor verlenging van die termijn voelt de minister niets, zo blijkt uit Kamerstukken I 2019/20, 35122, nr. C, p. 13-14.

37. Zie eveneens kritisch terzake RSJ, Consultatie Uitvoeringsbes/uit Wet straffen en beschermen, advies, Den Haag, 28 augustus 2020.
Dan het toetsingskader van penitentiair programma en v.i. In nauwe aansluiting bij het nieuwe toetsingskader voor verlofverlening, wordt ook dit kader gewijzigd met de Wet senb. De wet voorziet er immers in dat zowel voor de beslissing tot deelname aan een penitentiair programma (art. 4 lid 3 Pbw nieuw), als voor de beslissing tot v.i.-verlening (art. 6:2:10 lid $3 \mathrm{~Sv}$ nieuw) in ieder geval de drie voornoemde aspecten van het individueel gedrag van de gedetineerde, de belangen van slachtoffers en nabestaanden en tot slot de (recidive)risico's worden betrokken. Voor wat betreft het laatstgenoemd aspect is dat geenszins nieuw en voor wat betreft het gedragsaspect geldt eveneens dat dat nu al wordt meegewogen in de belangenafweging bij de beslissing over deelname aan een penitentiair programma (art. 7 lid 3 Pm). Bij de v.i. ligt dat wezenlijk anders. Bij de v.i. wordt het gedrag van de veroordeelde weliswaar meegewogen bij de beslissing om bijzondere voorwaarden aan de v.i.-verlening te stellen (art. 6:2:11 lid $2 \mathrm{~Sv}$ ) - mede daardoor blijkt de v.i.-regeling adequaat te zijn ingericht om de gewenste doelen van speciale preventie en re-integratie te kunnen realiseren ${ }^{38}$ - maar uitdrukkelijk niet bij de beslissing tot v.i.-verlening zelf. Van oudsher heeft de wetgever daarvan afgezien, ook bij de herinvoering van de voormaardelijke invrijheidstelling in 2008. ${ }^{39}$ Daarmee werd mede gehoor gegeven aan het advies van de Commissie Herziening vervroegde invrijheidstelling (Commissie-Vegter), die vreesde dat v.i.verlening - als ware een beloning voor goed gedrag - tot schijnaanpassingen bij gedetineerden kon leiden zonder relevantie voor het individuele gedrag na detentie. ${ }^{40}$ Twee decennia later is het (politieke) tij gekeerd. $\mathrm{Na}$ inwerkingtreding van de Wet senb, met inachtneming overigens op dit punt van het overgangsrecht, ${ }^{41}$ komt het gedrag wel degelijk aan de basis te liggen van elke beslissing over v.i.-verlening. Anders dan onder de nieuwe regeling van het penitentiair programma (art. 4 lid 3 Pbw nieuw) is dat niet gedefinieerd als 'de mate waarin en de wijze waarop is gebleken van goed gedrag', maar als 'de mate waarin en de wijze waarop de veroordeelde door zijn gedrag heeft doen blijken van een bijzondere geschiktheid tot terugkeer in de samenleving' (art. 15 lid 3 onder a Sr nieuw en art. 6:2:10 lid 3 onder a $\mathrm{Sv}$ nieuw). ${ }^{42}$ De gedetineerde moet het dus door middel van op re-integratie gerichte inspanningen gedurende zijn detentieperiode verdienen om die re-

38. Uit Beijerse e.a., a.w.

39. Kamerstukken // 2006/07, 30513, nr. 6, i.h.b. p. 1 en p. 4-5.

40. Rapport van de Commissie Herziening vervroegde invrijheidstelling, 2002, p. 26.

41. De wijzigingen van de Wet senb zijn niet van toepassing op de reeds genomen beslissingen over penitentiair programma voor de inwerkingtreding van de wet en evenmin voor wat betreft de v.i.-regeling op veroordelingen tot vrijheidsstraf die door de rechtbank of het gerechtshof zijn uitgesproken vóór de inwerkingtreding van de wet. Zie daarover B. Mulder \& S. Janssen, 'De herziening van de regeling voorwaardelijke invrijheidstelling', NJB 2018/3. Voor de wijziging van het verlofstelsel geldt overigens geen overgangsrecht, waardoor dat directe werking zal hebben.

42. Die laatste omschrijving komt wel grotendeels overeen met de omschrijving van goed gedrag in de nieuwe verlofregeling (art. 15 lid 2 onder a RTVI concept). 
integratie vervolgens onder algemene en bijzondere voorwaarden in de vrije samenleving nader gestalte te kunnen geven.

Deze insteek wordt bovendien wettelijk verankerd in de nieuwe formulering (art. 15 lid $1 \mathrm{Sr}$ nieuw en art. 6:2:10 lid $1 \mathrm{~Sv}$ nieuw) dat v.i. kan porden verleend, in plaats van de huidige formulering dat (de onder de doelgroep vallende) gedetineerde voorwaardelijk in vrijheid wordt gesteld. Over deze systeembreuk is al het nodige gezegd, ${ }^{43}$ maar toch kan ik het niet laten om ook hier te betogen dat voor deze breuk geen grond bestaat. Niet alleen berust het op een onterechte aanname over de vanzelfsprekendheid waarmee de v.i. thans zou worden verleend, maar ook behelst het voor de tenuitvoerlegging van de vrijheidsstraf niet louter een semantisch verschil, maar echt een fundamenteel andere normering. Waar het omwille van toch ook de maatschappelijke belangen van veiligheid en recidivebeperking wenselijk zou zijn als de v.i. als een positieve en met afdoende toezicht en begeleiding omgeven re-integratiemodaliteit wordt gezien, bestaat door de wetswijziging de vrees dat deze modaliteit eerst en vooral als negatief wordt beschouwd. Het wordt door de wetgever in ieder geval niet bijster aantrekkelijk gemaakt voor de gedetineerde om zijn v.i. ook daadwerkelijk te willen verdienen (nog afgezien of hij daartoe in staat is). Niet alleen heeft de Wet langdurig toezicht ervoor gezorgd dat de proeftijd van de v.i. kan worden verlengd met eenmalig ten hoogste twee jaar en bij zeden- en ernstige geweldsdelinquenten telkens met ten hoogste twee jaar, maar ook wordt met de Wet senb de periode waarvoor v.i. kan worden verleend gemaximeerd op twee jaar, hetgeen consequenties heeft voor de langgestraften. Voor de noodzaak tot, en legitimatie van, die maximering is nog altijd geen overtuigende onderbouwing gegeven. Dit geldt al helemaal voor de met het doel van detentiefasering tegenstrijdige redenering dat daarmee 'wordt voorkomen dat een groep veroordeelden jarenlang buiten de inrichting kan verblijven', 44 terwijl de redenering dat ingeval de twee jaar te kort blijkt te zijn er altijd nog gebruik kan worden gemaakt van de additionele toezichts- en begeleidingsmogelijkheden geboden door de Wet langdurig toezicht, ${ }^{45}$ een oneigenlijk gebruik van het wettelijk sanctiestelsel impliceert. Het aanscherpen

43. Onder meer P.C. Vegter, 'Voorwaardelijk in vrijheid met vertrouwen in de toekomst', Sancties 2018/4, p. 34-38; P.M. Schuyt, 'Voorwaardelijke invrijheidstelling: het beeld en de werkelijkheid', Sancties 2019/2, p. 5-13 en Struijk, a.w., 2020.

44. Kamerstukken / 2019/20, 35122, nr. E, p. 10.

45. Hetzij verlenging van de v.i.-proeftijd, hetzij toepassing van de zelfstandige gedragsbeïnvloedende en vrijheidsbeperkende maatregel (GVM, art. $38 \mathrm{z}$ Sr). Aan deze redenering dient echter - hoe men daar ook over moge denken - te worden toegevoegd, dat de GVM dan wel reeds in het veroordelend vonnis moet zijn opgelegd. De rechter kan deze maatregel namelijk niet ad hoc, na ommekomst van de (noodzakelijkerwijs eveneens in hetzelfde veroordelend vonnis opgelegde) gevangenisstraf, al dan niet na v.i., alsnog bepalen. Van de GVM als achtervang voor benodigd toezicht op de re-integratie, ook (en juist) ingeval geen v.i. aan de gedetineerde wordt verleend, wordt overigens veel heil verwacht. 'De GVM leent zich bij uitstek voor risicovolle gevallen, bij wie vrees bestaat voor een niet coöperatieve houding.' (Kamerstukken I 2019/20, 35122, nr. E, p. 6) van de v.i. wordt daarmee namelijk in feite gelegitimeerd met de mogelijke inzet van een (andere) toezichtsmodaliteit, die ingeval van een veroordeling voor een zeden- of ernstig geweldsdelict bovendien een mogelijk oneindige duur kent. Een dergelijke legitimatie staat haaks op de oorspronkelijke ideologie achter de v.i.-regeling om de vrijheidsstraf in te korten, teneinde een soepele, geleidelijke terugkeer naar de samenleving mogelijk te maken.

Een volgende, laatste bedenking bij de aantrekkelijkheid van de nieuwe v.i.-regeling - en daarmee de mogelijke effectiviteit ervan - is dat ook een gedetineerde die zijn v.i. wel wil verdienen en daar ook inspanningen toe verricht en verantwoordelijkheid in toont, er nog niet zeker van is of hem als 'beloning' ook daadwerkelijk v.i. wordt verleend. Net als bij de verlofbeslissing komen de externe slachtofferbelangen namelijk tevens aan de basis te liggen van de beslissing tot v.i.-verlening. Hoewel dit aspect als gezegd primair in de sleutel wordt geplaatst van de bescherming van het slachtoffer door middel van een contact- en/of locatieverbod en daarmee eenzelfde werking heeft als onder de huidige v.i.-regeling, wordt door de minister niet uitgesloten dat v.i.-verlening in het nieuwe stelsel achterwege blijft 'op het moment dat de gerechtvaardigde belangen van het slachtoffer - en in het bijzonder zijn (fysieke) veiligheid - niet op een andere wijze kunnen worden gewaarborgd' ${ }^{46}$ Het bevestigt eens te meer de insteek van de Wet senb dat slachtofferbelangen zwaarder gaan meewegen bij de beslissing om al dan niet externe vrijheden aan gedetineerden te verlenen. Het voert te ver om hier uitvoerig in te gaan op de principiële vraag of het juist is om slachtoffers een (grotere) stem te geven in de beslissingen inzake de tenuitvoerlegging van (vrijheidsbenemende) sancties, ${ }^{47}$ maar het is in mijn optiek een goede zaak dat de wetgever hierbij niet heeft geopteerd voor de directe procedure van een volledig spreekrecht inzake de v.i.-verlening, maar enkel voor de indirecte procedure dat slachtoffers hun zienswijze kenbaar kunnen maken ten aanzien van aan de v.i.-verlening te stellen bijzondere voorwaarden. ${ }^{48} \mathrm{Op}$ die manier wordt aansluiting gezocht bij de huidige werkwijze om tegemoet te komen aan de slachtofferbelangen, terwijl de beslissing over v.i.-verlening zo zuiver mogelijk wordt gehouden. Niettemin gaat de v.i.-praktijk wel contouren van spreekrecht vertonen, omdat het slachtoffer in zaken waarin de gedetineerde is veroordeeld voor een spreekrechtwaardig delict de mogelijkheid krijgt om de voornoemde zienswijze ook mondeling kenbaar te maken. ${ }^{49}$

46. Kamerstukken / 2019/20, 35122, nr. E, p. 4.

47. Voor een duidelijk bevestigend antwoord op deze vraag, zie A.K. Bosma, M.S. Groenhuijsen \& G.M. de Vries, 'De positie van het slachtoffer bij de voorwaardelijke invrijheidstelling en de voorwaardelijke beëindiging van de dwangverpleging in rechtsvergelijkend perspectief', DD 2020/13, p. 187-206.

48. Kamerstukken // 2018/19, 35122, nr. 6, p. 15-16 en 18. Deze indirecte procedure bij/via het Informatiepunt Detentieverloop wordt daarmee uitgebreid ten opzichte van de bestaande situatie ingeval van ernstige gewelds- en zedendelicten.

49. Kamerstukken // 2018/19, 35122, nr. 6, p. 16 en 58. 
Bovendien ligt een hellend vlak verscholen in het wetsvoorstel Uitbreiding slachtofferrechten, dat beoogt te voorzien in de invoering van een beperkt spreekrecht voor slachtoffers tijdens tbs-verlengingszittingen. ${ }^{50}$ Hoewel het wetsvoorstel kritisch is ontvangen, impliceert enkel de indiening ervan de mogelijkheid dat op termijn een wetssystematisch verschil ontstaat bij de executiebeslissingen inzake gevangenisstraf en tbs, waardoor de wetgever omwille van uniformiteit in het sanctiestelsel zomaar zou kunnen besluiten het spreekrecht alsnog ook bij de v.i.-regeling in te voeren. ${ }^{51}$

\section{Voorgenomen verscherpingen van het toetsingskader voor promoveren en degraderen}

Het voorgaande maakt duidelijk dat er voor het stelsel van detentiefasering heel wat op stapel staat na inwerkingtreding van de Wet senb. Waar dat nog enige tijd op zich laat wachten, staat een andere wijziging naar verwachting al veel eerder te gebeuren. De Minister voor Rechtsbescherming kondigde het enige tijd geleden al aan: om de wijze waarop de gedetineerde zich inzet voor de afspraken uit het D\&R-plan en dus voor diens re-integratie zo helder mogelijk te kunnen beoordelen, wordt het toetsingskader inzake het promoveren-endegraderen-programma aangescherpt. ${ }^{52}$ Concreet dient dit gestalte te krijgen door wijziging van de Regeling SPOG. De inwerkingtreding daarvan was beoogd voor 1 september 2020, van welke datum ook 'achter de schermen' is uitgegaan bij de bekendmaking en verspreiding van het gewijzigd toetsingskader in alle penitentiaire inrichtingen en onder alle ketenpartners. Op het moment van afronding van deze bijdrage, medio september, is de betreffende wijziging van de Regeling SPOG echter nog niet geformaliseerd. Dit zal ongetwijfeld mede te maken hebben met het kritische advies dat de RSJ uitbracht over de voorgenomen wijziging. ${ }^{53}$ Ondanks dat er dus nog niets zeker is, valt, gebaseerd op de eerder door de minister geduide plannen en op de inhoud van het RSJ-advies, het volgende te zeggen over de voorgenomen wijziging.

Het befaamde stoplichtmodel van groen (gewenst), oranje (dit kan beter) en rood (ongewenst) gedrag - geformaliseerd als bijlage 1 bij de Regeling SPOG wordt vervangen door een duaal model van enkel de

50. Kamerstukken II 2019/20, 35349, nrs. 1-3.

51. Zie voor een weergave van de kritische ontvangst van het wetsvoorstel alsook een signalering van het genoemde wetssystematische verschil: Bosma e.a., a.w.

52. Kamerstukken II 2018/19, 35122, nr. 6, p. 20-21; Kamerstukken I 2019/20, 35122, nr. E, p. 9 en bijlage bij Kamerstukken / 2019/20, 35122, nr. G, p. 5.

53. RSJ, Promoveren en degraderen in detentie, advies, Den Haag, 17 juli 2020. twee uitersten van gewenst en ongewenst gedrag. Daarmee komt de tussencategorie te vervallen, hetgeen volgens het RSJ-advies is bedoeld als vereenvoudiging van het toetsingskader. Bovendien zou deze categorie - volgens de in het advies op onderdelen fors bekritiseerde toelichting - 'in de praktijk niet nodig zijn aangezien het gedrag van gedetineerden in het dagelijkse contact doorlopend door medewerkers beoordeeld en besproken wordt', waarbij gedetineerden worden gewezen op hun gedrag en indien nodig gewaarschuwd. ${ }^{54}$ Over de kwaliteit van die beoordeling is echter veel te doen in de praktijk, ${ }^{55}$ terwijl het nog enkel afgeven van informele waarschuwingen aan de gedetineerden vanuit het perspectief van rechtsbescherming onmiskenbaar een achteruitgang betekent ten opzichte van de huidige in het toetsingskader verankerde en door het MDO (namens de directeur, art. 1d lid 2 Regeling SPOG) afgegeven oranje-kleuring. Het beoogde nieuwe duale model heeft bovendien een 'alles of niets'-karakter, waardoor het niet alleen de verhoudingen tussen personeel en gedetineerden (verder) op scherp kan stellen, maar ook de druk op de beklag- en beroepsrechtspraak (verder) kan opvoeren. Reeds om die reden onderschrijf ik ten volle de aanbeveling van de $\mathrm{RSJ}^{56}$ om voorafgaand aan de voorgenomen wijziging van de Regeling SPOG eerst een degelijke evaluatie uit te voeren van het promoveren-en-degraderen-programma, om te bezien in hoeverre er legitieme grond bestaat om de tussencategorie te laten vervallen.

Het belang van zo'n evaluatie geldt des te meer nu het voornoemd 'alles of niets'-karakter zelfs nog wordt versterkt doordat het promoveren en degraderen als zodanig een wezenlijk andere functie verkrijgt met de inwerkingtreding van de Wet senb. Waar het nu enkel ziet op het bij wijze van beloning voor gewenst gedrag verkrijgen van meer interne vrijheden - kort gezegd behelst het plusprogramma in totaal 59 uur aan activiteiten in plaats van de 43 uur in het basisprogramma en zijn er extra activiteiten op het gebied van onderwijs, arbeid en re-integratie - wordt dat met de wet uitgebreid naar de toekenning van externe vrijheden in de vorm van re-integratieverlof, deelname aan een penitentiair programma en/of v.i. Zo bezien komt voor de doorfasering straks veel meer, zo niet alle, gewicht te hangen aan de (beslissing tot) promotie naar het plusprogramma.

De gedachte daarachter is dat de gedetineerde door middel van zijn gedrag en inspanningen tijdens detentie de 'sleutel in handen heeft voor een geslaagde terugkeer in de vrije maatschappij'. ${ }^{57}$ Daar logischerwijs mee samenhangend, komt de nadruk in het nieuwe toetsingskader veel meer te liggen op de inspanningen die

\footnotetext{
54. Ibidem, p. 8.

55. Zie daarover nader RSJ, a.w., 2019 en Inspectie JenV, Uit Balans. Een onderzoek naar de kwaliteit van de taakuitvoering in zes locaties binnen het gevangeniswezen, Den Haag 2018.

56. RSJ, a.w.. 17 juli 2020, p. 16.

57. Kamerstukken // 2018/19, 35122, nr. 3, p. 6.
} 
door de gedetineerde worden verricht om zijn re-integratiedoelen te behalen. ${ }^{58}$ Deze nadruk op de verantwoordelijkheid voor re-integratie is van meet af aan door zowel de beleidsmakers als de RSJ als grondslag voor degradatie gehanteerd ${ }^{59}$ In zoverre kan een versteviging van die nadruk in de rede liggen. Niet duidelijk is echter waarom ter zake wordt beoogd de huidige drie onderdelen waarop het individuele gedrag wordt beoordeeld - veiligheid en beveiliging; zorg en begeleiding en reintegratie en resocialisatie - terug te brengen tot enkel het gedrag gericht op het verblijf en de leefbaarheid in de inrichting - bijvoorbeeld het zich houden aan huisregels - en het gedrag gericht op re-integratie en herstel bijvoorbeeld het deelnemen an re-integratieactiviteiten. ${ }^{60}$ Ingegeven door de hoge administratieve druk in de dagelijkse penitentiaire praktijk zouden de twee beoogde onderdelen zomaar kunnen verworden tot brede, abstracte containergedragingen, die afbreuk doen aan de kwaliteit van de motivering van de promotie- en degradatiebeslissingen, zo signaleert ook de RSJ ${ }^{61}$ En juist op dat punt ziet de beroepscommissie van de RSJ scherp toe. Als vaste jurisprudentie heeft te gelden dat niet elk ongewenst gedrag tevens een gebrek aan verantwoordelijkheid voor de eigen re-integratie hoeft in te houden en dat zodoende van de directeur van de penitentiaire inrichting een kenbare, deugdelijke en inzichtelijke belangenafweging wordt gevergd, met inachtneming van het structurele (groene) gedrag van de gedetineerde ${ }^{62}$ En juist op dat punt lijkt met de voorgenomen wijziging van het toetsingskader forse afbreuk te worden gedaan. Naast de voornoemde beoogde nieuwe categorieën van 'gewenst' en 'ongewenst' gedrag, wordt namelijk nog een derde categorie beoogd van 'ontoelaatbaar gedrag'. Volgens het RSJ-advies zou het daarbij gaan om 'gedragingen waarbij op grond van één enkel incident degradatie kan plaatsvinden', zonder de benodigde belangenafweging. ${ }^{63}$ Het moge voor zich spreken dat de RSJ de introductie van deze gedragscategorie als onwenselijk beschouwt. Dit klemt des te meer, nu de beoogde gedragingen die volgens het advies onder deze gedragscategorie zouden worden geschaard, allen reeds als rood, ongewenst gedrag kunnen worden bestempeld. Deze gedragingen kunnen dus als zodanig al tot degradatie leiden, mits daarbij dan wel een belangenafweging wordt gemaakt. ${ }^{64}$ Het zou in mijn optiek zeer laakbaar zijn als die in de rechtspraak gestelde waarborg van

58. Kamerstukken / 2019/20, 35122, nr. E, p. 9 en bijlage 938174, p. 5, opgenomen bij Kamerstukken I 2019/20, 35122, nr. G.

59. Standaardjurisprudentie sinds BC 10 november 2014, 14/1918/GA; BC 16 maart 2015, 14/3222/GA en BC 19 januari 2016, 15/3498/GA.

60. Kamerstukken // 2018/19, 35122, nr. 6, p. 20-21.

61. RSJ, a.w., 17 juli 2020, p. 9

62. Onder meer in BC 31 oktober 2018, R-499; BC 3 december 2018, R-18/1693/GA; BC 14 februari 2019, R-18/1273/GA en BC 30 september 2019, R-19/2499/GA.

63. RSJ, a.w., 17 juli 2020, p. 10-11

64. BC 10 november 2014, 14/1918/GA. De enige uitzondering die hier in de rechtspraak op wordt gemaakt, betreft een (poging tot) ontvluchting tijdens een transport, waarbij gelet op de aard van dit ongewenste gedrag in relatie tot de gevergde eigen verantwoordelijkheid voor reintegratie onmiddellijke degradatie is toegestaan (BC 13 november 2014, 14/2591/GA en BC 12 december 2014, 14/4565/SGA). overheidswege bewust wordt omzeild. Hierbij kan bovendien in herinnering worden geroepen de in 2006 in het kader van detentiefasering geuite waarschuwing voor een te rigide toetsingskader, omdat 'sturing en beïnloeding van het besluitvormingsveld via meer (dwingende) regels niet per definitie de beste of enig mogelijke strategie' is. ${ }^{65}$

\section{Slot}

Met het voorgaande zijn nog lang niet alle ontwikkelingen in de penitentiaire wet- en regelgeving, praktijk en rechtspraak geduid. Volledigheid was ook niet het streven voor deze bijdrage. Dat zou niet alleen ondoenlijk zijn in het bestek van de bijdrage, maar zou bovendien het gevaar met zich brengen dat het één grote klaagzang wordt en daar zit niemand op te wachten. Het ging mij er veeleer om mijn zorgen te uiten over een grootscheeps, onderling samenhangend veranderproces, waarvan op onderdelen de legitimatie rammelt, de noodzaak onduidelijk is en de consequenties voor de uitvoeringspraktijk groot zijn. De al langer aan het penitentiair beleid ten grondslag liggende idee dat de toekenning aan gedetineerden van interne vrijheden afhankelijk moet zijn van de mate waarin zij verantwoordelijkheid tonen voor hun eigen re-integratie, was mede gebaseerd op de behoefte in de samenleving aan wederkerigheid en balans. ${ }^{66}$ Dit geldt thans, met de op de Wet senb gefundeerde uitbreiding van die verantwoordelijkheidsmaatstaf naar de toekenning van externe vrijheden en de mogelijkheden tot doorfasering, nog onverkort. De huidige kabinetsvisie op de tenuitvoerlegging van gevangenisstraffen benadrukt het vergeldend kenmerk van deze straf en gaat uit van een wijze van tenuitvoerlegging die meer recht doet 'aan het rechtvaardigheidsgevoel van slachtoffers, nabestaanden en de hele samenleving', waarbij het aan de individuele gedetineerde is om de aan hem geboden kansen 'ook echt met beide handen aan te pakken'. ${ }^{67}$ Het is met alle (voorgenomen) wijzigingen zeer de vraag of gedetineerden op hun beurt ook een wederkerigheid ervaren. Bovendien zou het eveneens wederkerige - individueel en maatschappelijk - belang van een succesvolle re-integratie wel eens tegen een te hoge prijs kunnen worden nagestreefd, doordat de blik is gericht op de veiligheid gedurende de periode na detentie, terwijl daaraan voorafgaand de verhoudingen gedurende de detentieperiode meer en meer op scherp worden gesteld en de rechtspositie van gedetineerden wordt verzwakt.

65. Nelissen, a.w., p. 15.

66. R. Krabbendam \& P. Nelissen, 'Het gevangeniswezen op de schop: de ambities van het Programma Modernisering Gevangeniswezen', Sancties 2012/35, alsook T. Molleman \& A.A. van den Hurk, 'Een kwestie van evenwichtskunst: Over doelen en taken van het gevangeniswezen', DD 2012/42, p. 576-590.

67. Visie Recht doen, kansen bieden, a.w., p. 2. 